\title{
Evaluating the auralization of a small room in a virtual sound environment using objective room acoustic measures
}

\author{
Ahrens, Axel; Marschall, Marton; Dau, Torsten
}

Publication date:

2016

Document Version

Publisher's PDF, also known as Version of record

Link back to DTU Orbit

Citation (APA):

Ahrens, A., Marschall, M., \& Dau, T. (2016). Evaluating the auralization of a small room in a virtual sound environment using objective room acoustic measures. Poster session presented at 5th Joint Meeting of the Acoustical Society of America and Acoustical Society of Japan, Honolulu, Hawaii, United States.

\section{General rights}

Copyright and moral rights for the publications made accessible in the public portal are retained by the authors and/or other copyright owners and it is a condition of accessing publications that users recognise and abide by the legal requirements associated with these rights.

- Users may download and print one copy of any publication from the public portal for the purpose of private study or research.

- You may not further distribute the material or use it for any profit-making activity or commercial gain

- You may freely distribute the URL identifying the publication in the public portal

If you believe that this document breaches copyright please contact us providing details, and we will remove access to the work immediately and investigate your claim. 


\section{( 3 PAAb2 Evaluating the auralization of a small room in a virtual sound environment using objective room acoustic measures}

Axel Ahrens, Marton Marschall, Torsten Dau

Hearing Systems group, Technical University of Denmark, Lyngby, Denmark aahr@elektro.dtu.dk

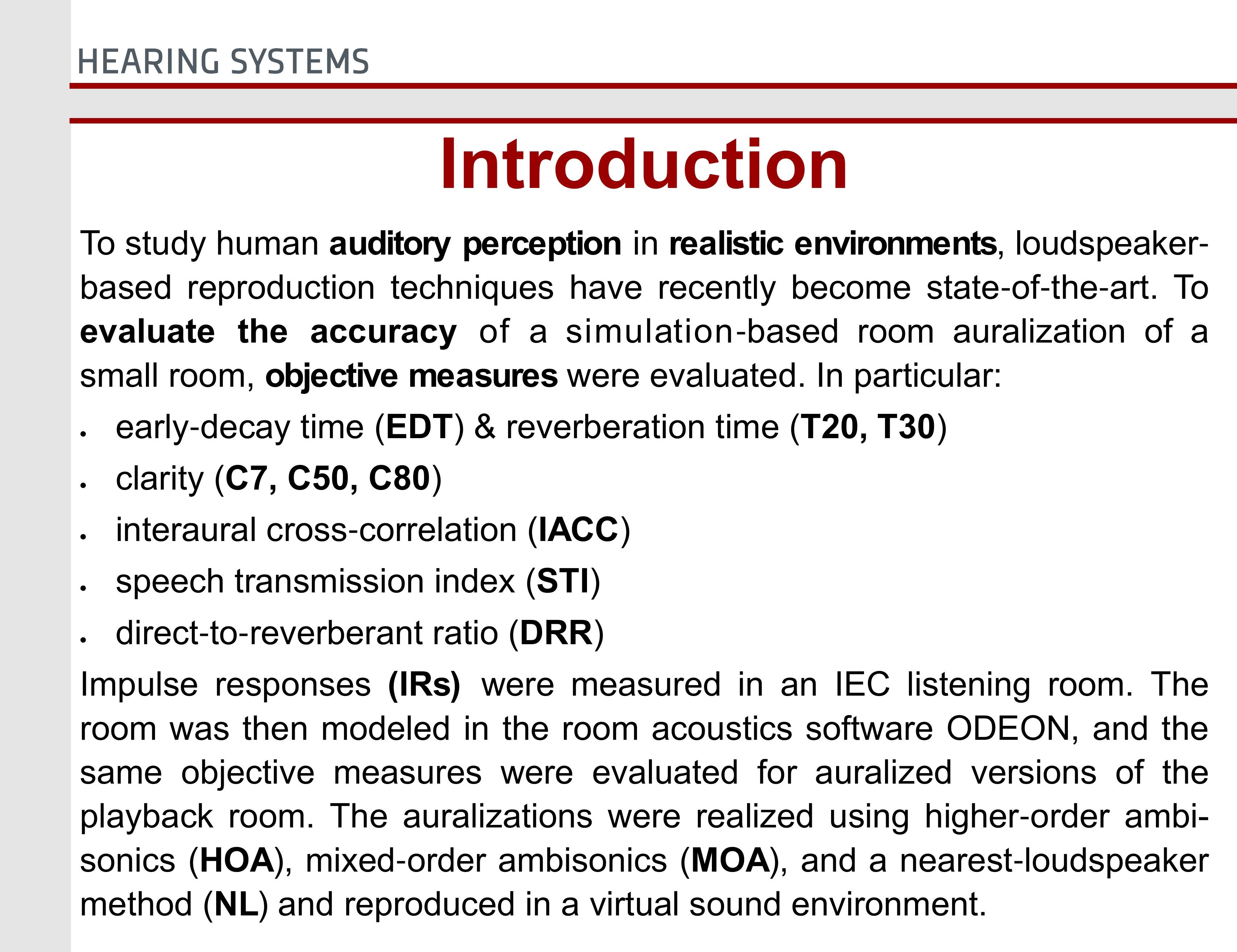

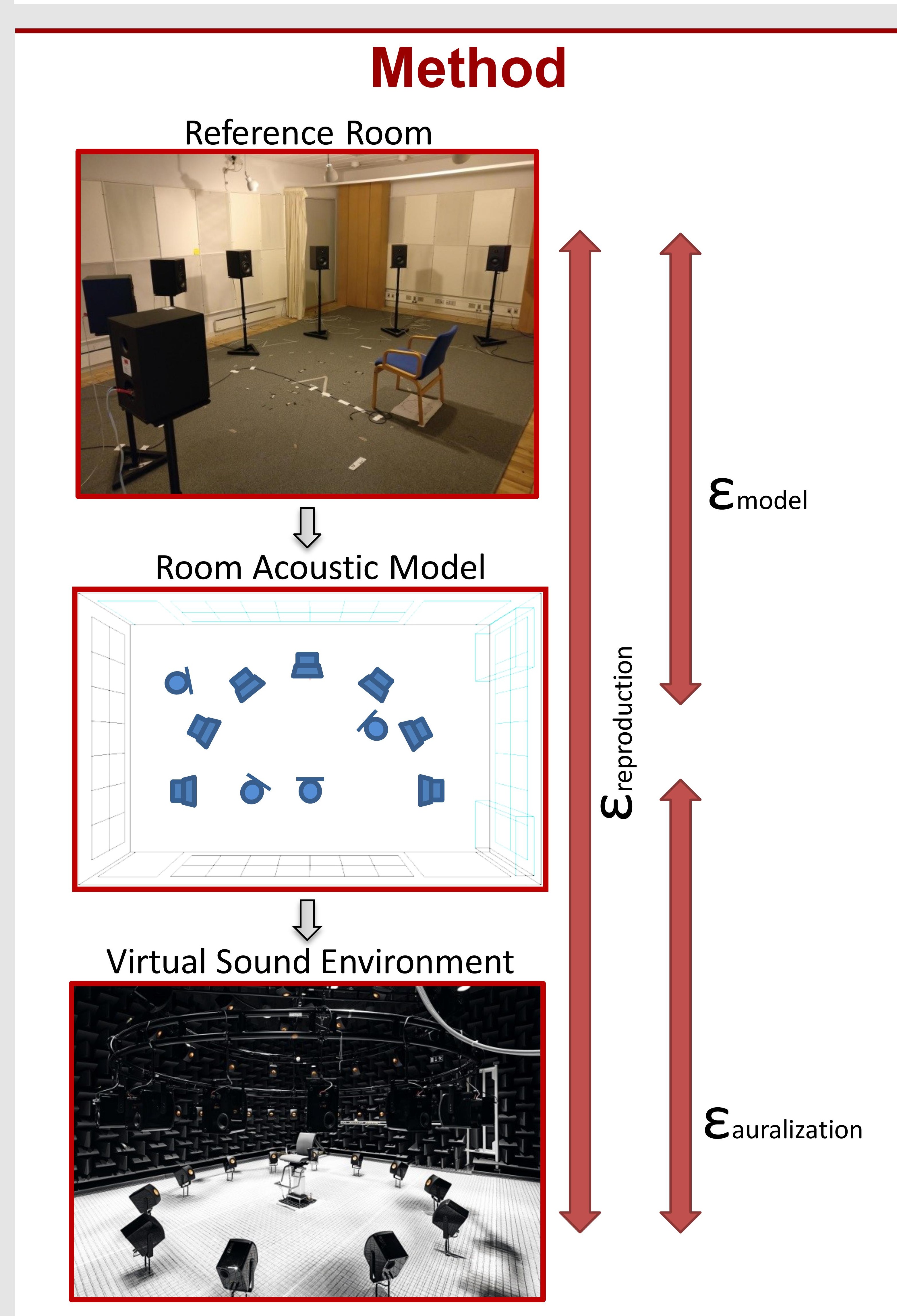

Reproduction techniques

Higher lordspeaker (NL; Favrot\&Buchholz, 2010)

. Higher-order ambisonics (HOA, 5th order)
. Mixed-order ambisonics (MOA, 7th/5th order; Daniel, 2000)

Modeling

DDEON V13.04 (Rindel\&Aaylor, 1991) model of IEC listening $\left.75^{*} 2.8 \mathrm{~m}\right)$

Material properties optimized using ODEON's genetic

material optimizer (Christensen et al., 2014)

IR recording

(D)

4 rece)

Processing and analysis using ITA-loobox and Two Ears

Processing
framework
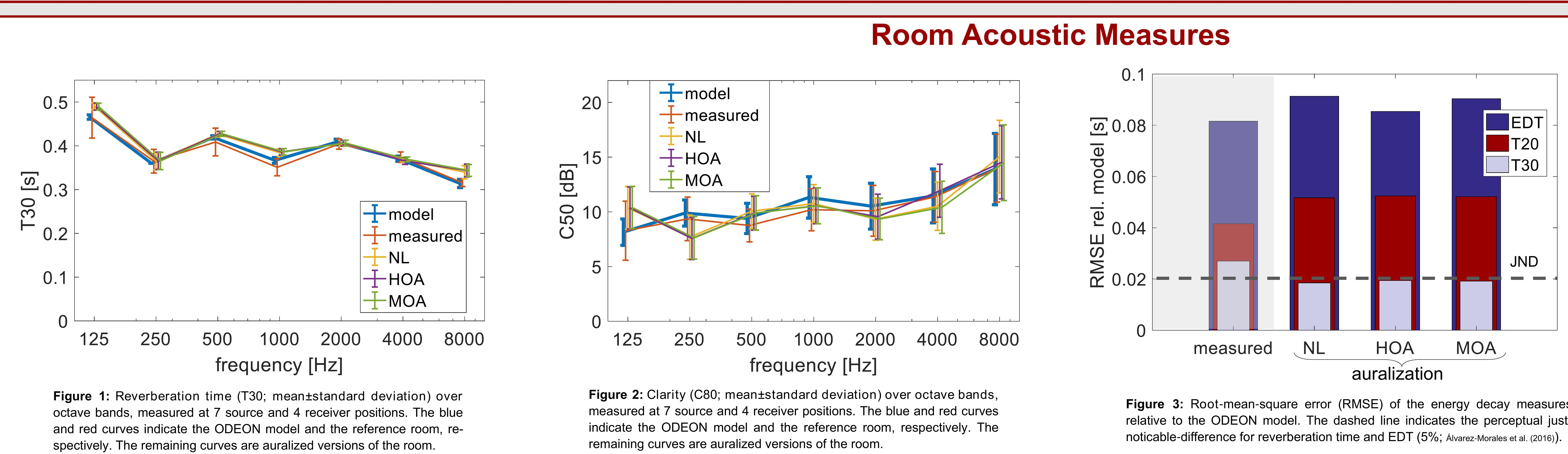

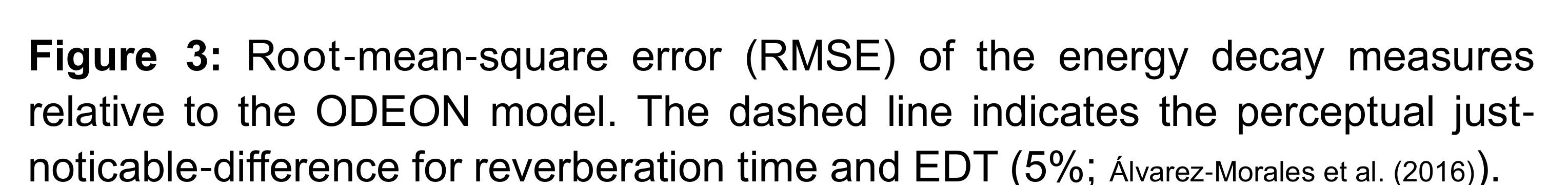

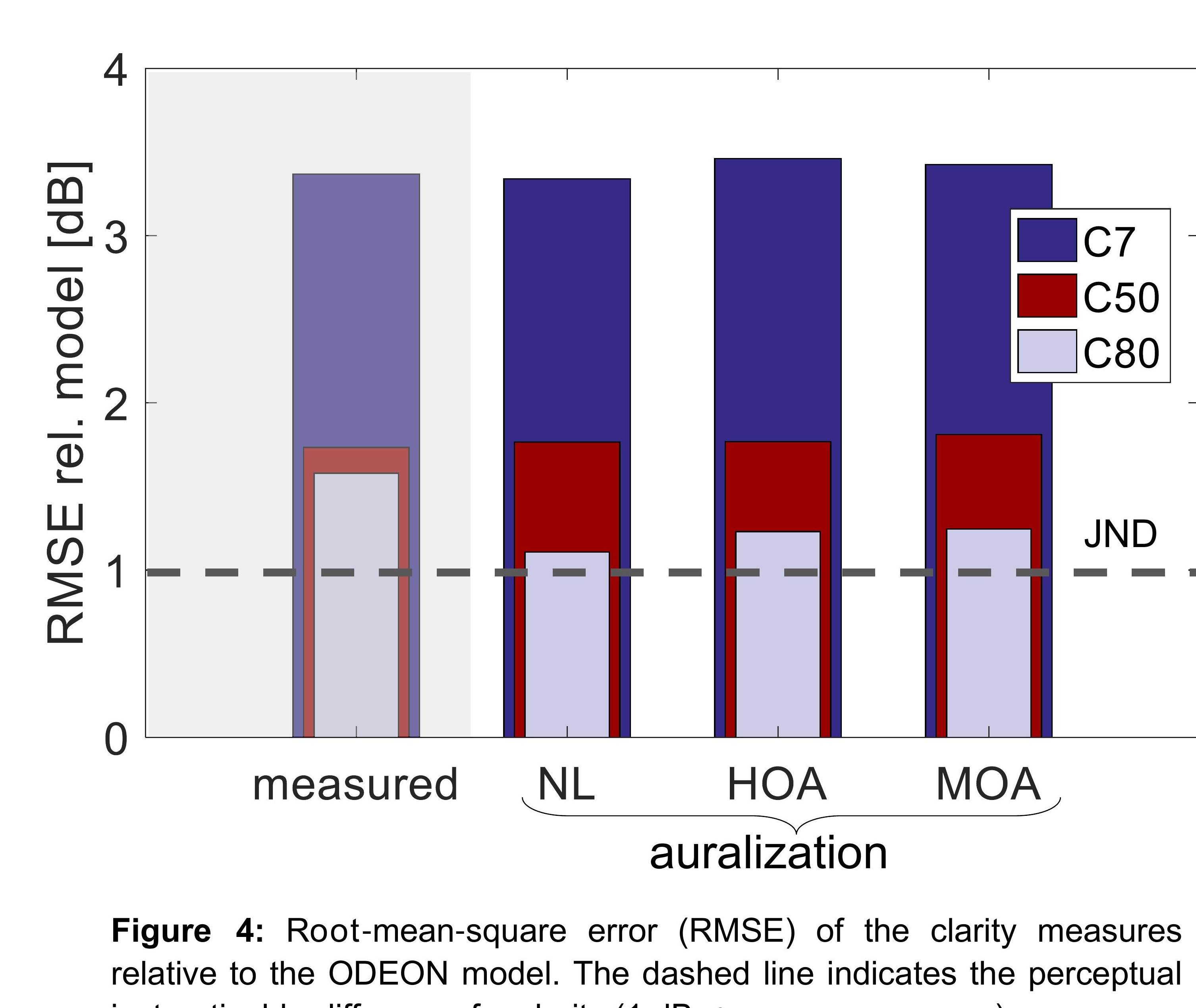

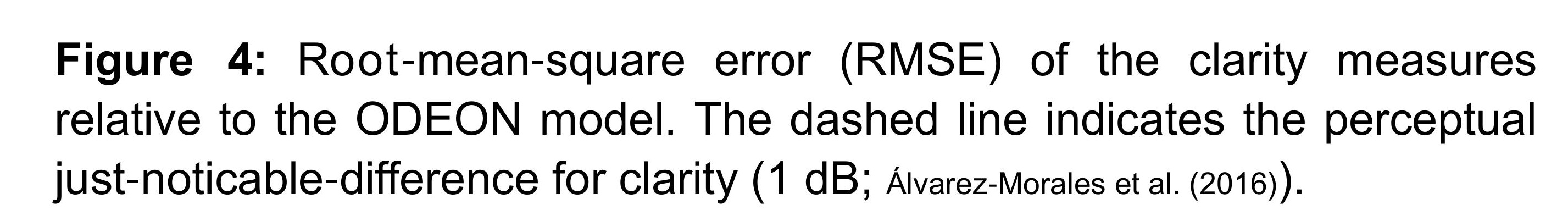

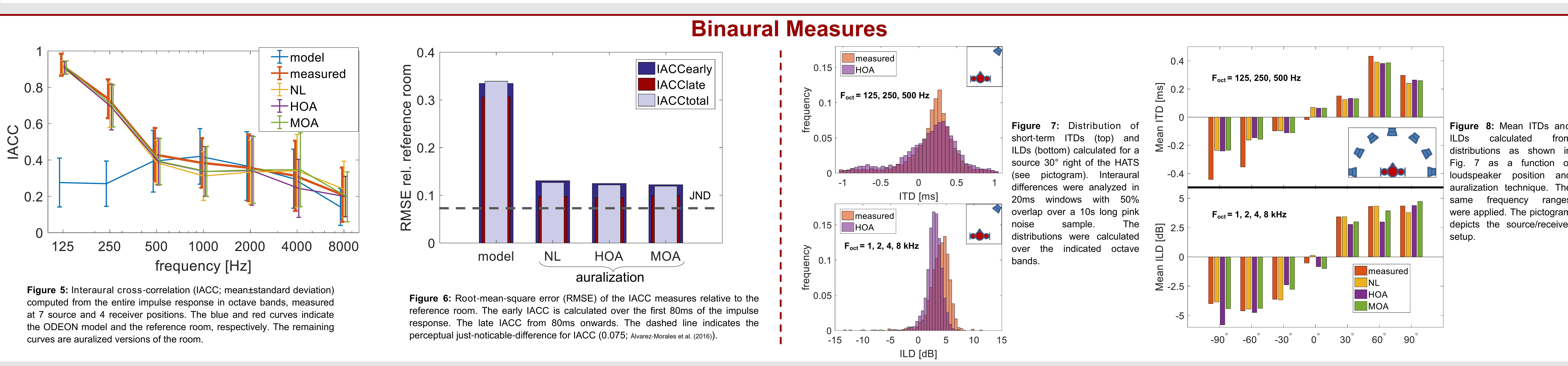

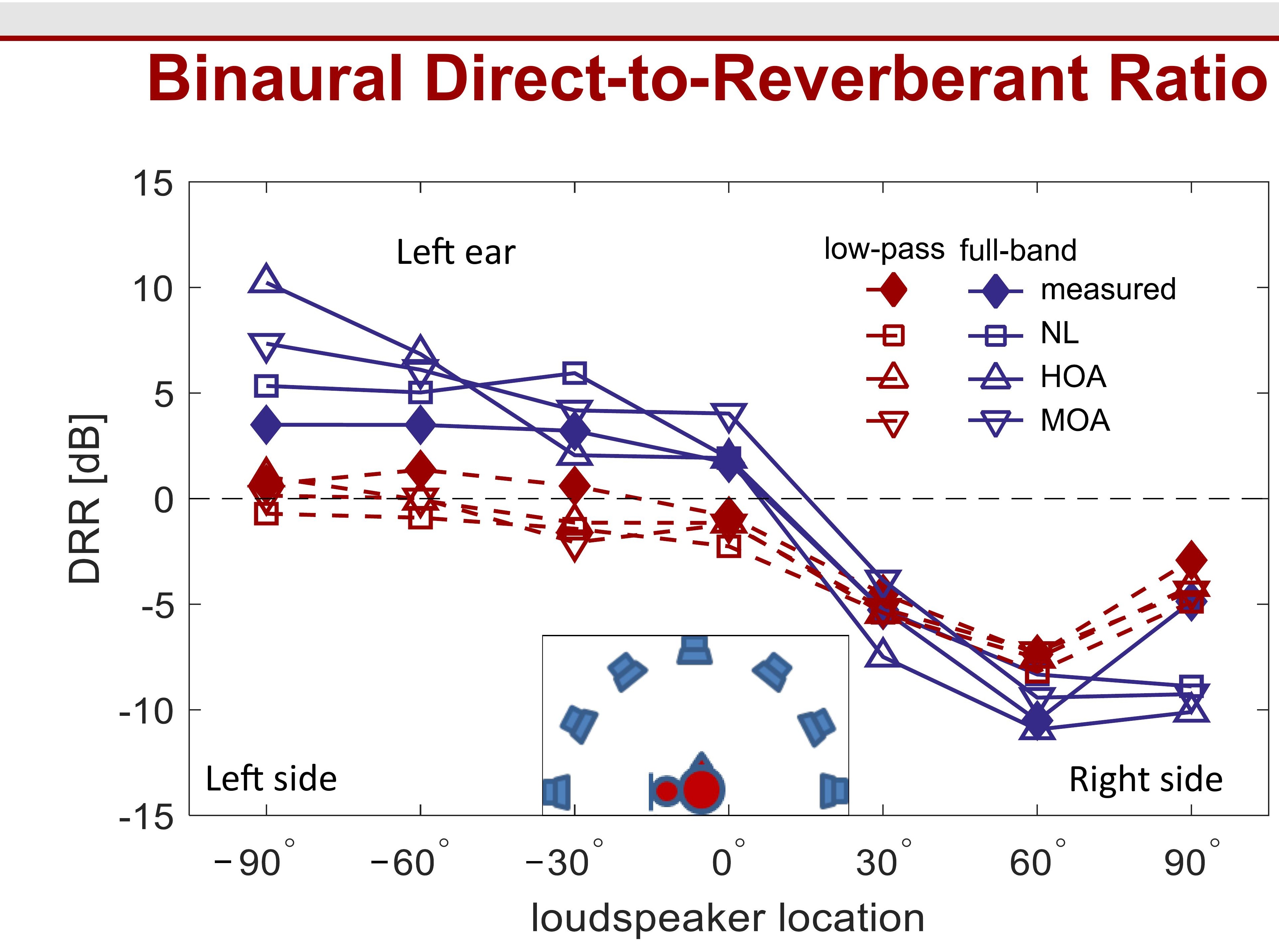

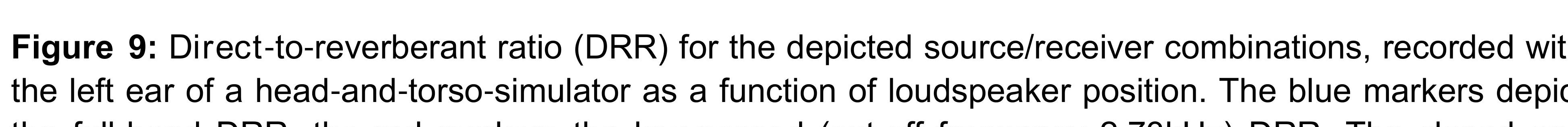

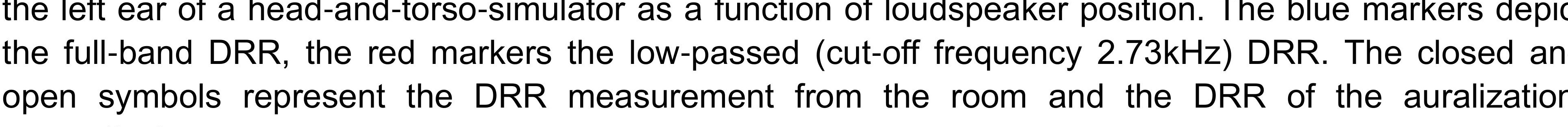

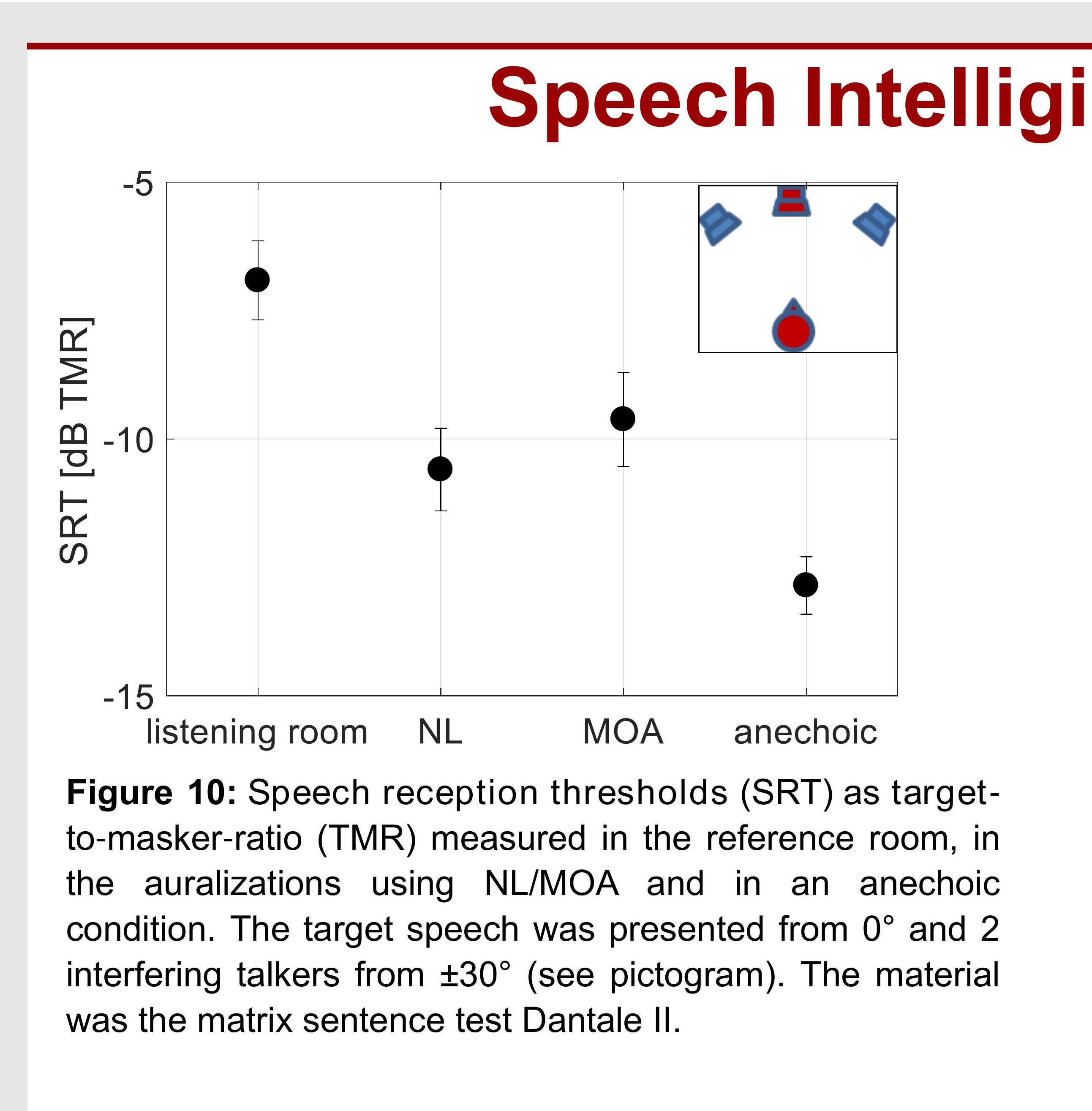

Literature

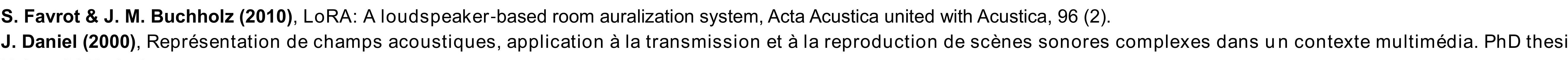

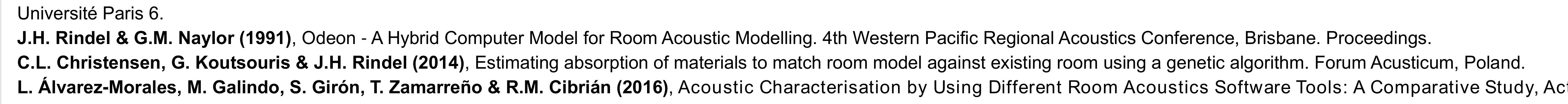

\begin{tabular}{|c|c|}
\hline \multicolumn{2}{|c|}{$\begin{array}{l}\text { - Long-term, averaged measures are reproduced in the range of } \sim 1 \mathrm{JND} \\
\text { (T20/30, C50/80, STI, IACC) }\end{array}$} \\
\hline \multicolumn{2}{|c|}{$\begin{array}{l}\text { Short-term features of the impulse response are more difficult to capture } \\
\text { leading to higher errors in e.g. EDT and C7 }\end{array}$} \\
\hline \multicolumn{2}{|c|}{-Similar performances were obtained across reproduction techniques } \\
\hline \multicolumn{2}{|c|}{$\begin{array}{l}\text {-Auralization errors (auralization vs. model) are in the range of modeling } \\
\text { errors (model vs reference) }\end{array}$} \\
\hline \multicolumn{2}{|c|}{ Dynamic binaural cues appear to be well captured } \\
\hline \multicolumn{2}{|c|}{$\begin{array}{l}\text { Perceptual differences (e.g. speech intelligibility) occur, but not reflected } \\
\text { in shown objective measures }\end{array}$} \\
\hline \multicolumn{2}{|c|}{$\begin{array}{l}\Rightarrow \text { Further investigations needed to link perceptual differences to objective } \\
\text { measures }\end{array}$} \\
\hline & 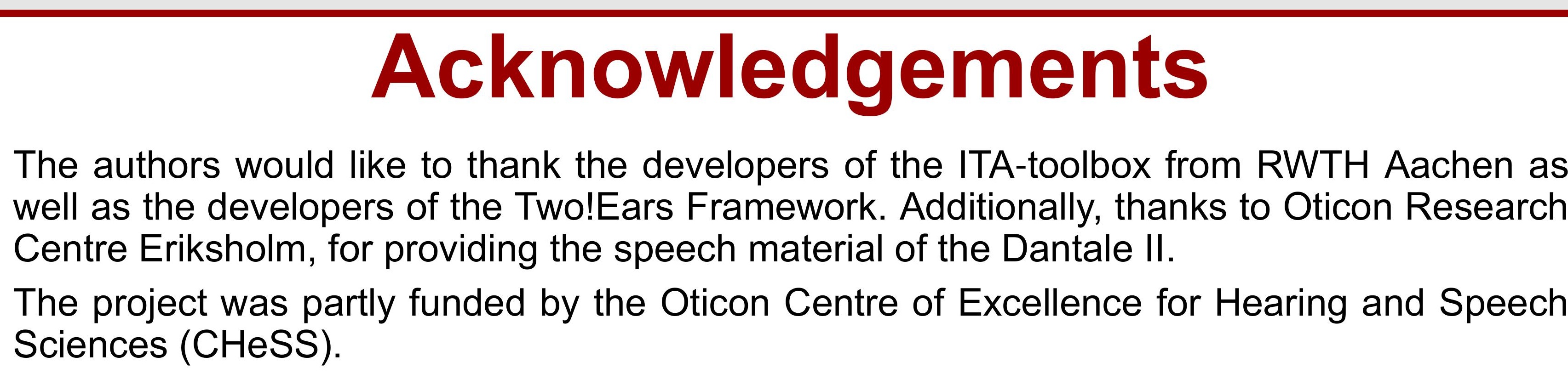 \\
\hline
\end{tabular}

